\title{
Development of a Chimeric DNA-RNA Hammerhead Ribozyme Targeting SARS Virus
}

\author{
Akiko Fukushima $^{a}$ Noboru Fukudab,c Yimu Laic ${ }^{\mathrm{c}}$ Takahiro Ueno ${ }^{c}$ \\ Mitsuhiko Moriyama ${ }^{a}$ Fumihiro Taguchid ${ }^{d}$ Akifumi lguchi $^{b}$ Kazushi Shimizu $^{\mathrm{e}}$ \\ Kazumichi Kuroda ${ }^{\mathrm{e}}$ \\ a Division of Gastroenterology and Hepatology, Department of Medicine, Nihon University School of Medicine, \\ ${ }^{b}$ Advanced Research Institute of the Science and Humanities, Nihon University Graduate School, 'Division of \\ Nephrology, Hypertension and Endocrinology, Department of Medicine, Nihon University School of Medicine, \\ ${ }^{\mathrm{d}}$ Department of Virology III, National Institute of Infectious Disease, and e Department of Immunology and \\ Microbiology, Nihon University School of Medicine, Tokyo, Japan
}

\section{Key Words}

Ribozyme $\cdot$ Antiviral $\cdot$ Mouse hepatitis virus $\cdot$ SARS virus

\begin{abstract}
Objective: Severe acute respiratory syndrome (SARS) is a severe pulmonary infectious disease caused by a novel coronavirus. To develop an effective and specific medicine targeting the SARS-coronavirus (CoV), a chimeric DNA-RNA hammerhead ribozyme was designed and synthesized using a sequence homologous with the mouse hepatitis virus (MHV). Method: Chimeric DNA-RNA hammerhead ribozyme targeting MHV and SARS-CoV were designed and synthesized. To confirm its activity, in vitro cleavage reactions were performed with the synthesized ribozyme. Effects of the chimeric ribozyme were evaluated on multiplication of MHV. Effects of the chimeric ribozyme on expression of SARS-CoV were evaluated in cultured 3T3 cells. Result: The synthetic ribozyme cleaved the synthetic target MHV and SARS-CoV RNA into fragments of predicted length. The chimeric DNARNA hammerhead ribozyme targeting SARS-CoV significantly inhibited multiplication of MHV in DBT cells by about $60 \%$. The chimeric DNA-RNA hammerhead ribozyme target-
\end{abstract}

ing SARS-CoV significantly inhibited the expression of SARSCoV RNA in 3T3 cells transfected with the recombinant plasmid. The chimeric DNA-RNA ribozyme targeting SARS-CoV significantly inhibited MHV viral activity and expression of recombinant SARS RNA in vitro. Conclusion: These findings indicate that the synthetic chimeric DNA-RNA ribozyme could provide a feasible treatment for SARS.

Copyright $\odot 2009$ S. Karger AG, Basel

\section{Introduction}

Severe acute respiratory syndrome (SARS) is a new infectious disease caused by a novel coronavirus that leads to deleterious pulmonary pathological features. During the peak of the SARS outbreak between November 2002 and June 2003, 8,437 cases were reported with 813 deaths [1]. The causative organism has been identified as a novel coronavirus (SARS-CoV) [2, 3]. The overall mortality during the outbreak was estimated at 9.6\% [4, 5]. The overriding clinical feature of SARS is the rapidity by which many patients develop symptoms of acute respiratory distress syndrome.

\section{KARGER}

Fax +41613061234 E-Mail karger@karger.ch www.karger.com (c) 2009 S. Karger AG, Basel

0300-5526/09/0522-0092\$26.00/0

Accessible online at:

www.karger.com/int
Noboru Fukuda, MD, PhD

Advanced Research Institute for the Sciences and Humanities

Nihon University, Ooyaguchi-kami 30-1, Itabashi-ku

Tokyo 173-8610 (Japan)

Tel. +81 33972 8111, Fax +81 33972 8666, E-Mail fukudan@med.nihon-u.ac.jp 
The full-length genome sequence of the SARS-CoV indicates that it is an enveloped, positive-stranded RNA virus from the family Coronaviridae, which have the largest known nonsegmented viral RNA genome (up to $31 \mathrm{~kb}$ ). The large corona of distinctive spikes in the envelope of coronaviruses makes their identification possible by electron microscopy. Various drugs have been applied to treat patients who contract SARS. Specific new drugs $[6,7]$ and vaccines $[8]$ to SARS-CoV have been widely developed. However, specific cures are yet to be produced for SARS. Thus, further experimental and clinical research is required to produce effective therapeutic agents, nucleic acid medicines show promise in this area.

Engineered inactivation of gene function is important for elucidating the function of particular genes, and may also be used in gene therapy, treatment of viral infection, cancer, and other diseases caused by aberrant gene expression. Gene function can be inactivated at the DNA level by nucleic acid medicines such as antisense oligodeoxynucleotides, or at the RNA level by ribozymes and siRNAs. The development of a specific molecular antiviral therapy would be a landmark advance in medical care. A major stumbling block to this has been the achievement of specificity: compounds toxic to a virus are most often also toxic to the host cell in which these obligate intracellular pathogens reside. Recently, antisense technologies, in which specificity is conferred at the level of the nucleic acid sequence, have been tested for therapeutic potential. One such approach utilizes ribozymes. $\mathrm{Ri}$ bozymes are RNA molecules that hybridize and cleave specific target RNAs. Once the target has been cleaved, the ribozyme can dissociate from the cleaved transcript and repeat the process with another RNA molecule [9]. The major advantage of ribozymes is that they can sequence-specifically cleave multiple target mRNA molecules, whereas antisense molecules do not cleave the target molecule themselves, but rely on the RNAi machinery, and act only at an equimolar ratio [10]. In the last 15 years, ribozymes have progressed from subjects of scientific study to potential therapeutic agents for treatment of both acquired and inherited diseases [3]. We have developed chimeric DNA-RNA hammerhead ribozymes targeted against growth factors for cardiovascular and renal diseases [11, 12]. Ribozymes have been shown to successfully inhibit gene expression in cancer [13] and human immunodeficiency virus [14]. This demonstrates the promise of this technology.

Ribozymes are easily degraded by RNase in vivo, hence it will be difficult for them to be applied against chronic disease. However, ribozymes could still be used successfully for acute diseases such as SARS. In this study a ribozyme specific for SARS was developed. A chimeric DNA-RNA hammerhead ribozyme was designed and synthesized to target a common nucleotide sequence between SARS-CoV and mouse hepatitis virus (MHV), and its effectiveness on suppression of MHV and SARS-CoV RNA expression evaluated in vitro.

\section{Materials and Methods}

Design and Structure of Chimeric DNA-RNA Hammerhead Ribozyme Targeting MHV and SARS-CoV

To avoid double-stranded structure after the target GUC cleavage site, the secondary structure of SARS-CoV RNA (NC_ 004718) was analyzed using the 'GENETYX-MAC: Second Structure and Minimum Free Energy' software package. The analysispredicted GUC sequence is located at nucleotides 15460-15462 and should be in a loop structure in SARS-CoV (fig. 1). The target homologous RNA sequences around the cleavage site for SARSCoV RNA and MHV RNA are shown in figure 2a. A 38-base chimeric DNA-RNA hammerhead ribozyme was designed in which ribonucleotides at noncatalytic residues were replaced with deoxyribonucleotides, and with two phosphorothioate linkages at the 3 '-terminus for cleavage after the GUC sequence. A mismatch ribozyme with a three-base change in the catalytic core was designed as a control (fig. 2b).

\section{Synthesis of Ribozymes and Synthetic Target Viral RNA with}

\section{T7 RNA Polymerase}

Ribozyme and target RNA were synthesized using T7 RNA polymerase and synthetic DNA template as described previously $[15,16]$. The active template DNA strand containing the region from -17 to -1 of the class III T7 RNA polymerase promoter followed by the complement of RNA sequence desired, was made.

For RNA synthesis, $3 \mu \mathrm{g}$ of annealed template was mixed with $6 \mu \mathrm{l}$ of T7 RNA polymerase (50 U/ $\mu$ l, Takara Biochemicals, Osaka, Japan), $5 \mu$ l of $\alpha-{ }^{32} \mathrm{P}-\mathrm{CTP}$ (specific activity 3,000 Ci/mM, New England Nuclear), $50 \mathrm{U}$ of RNase inhibitor (Takara Biochemicals) and $50 \mu \mathrm{l}$ of transequence-scription reaction buffer $[40 \mathrm{mM}$ Tris$\mathrm{HCl}$ (pH 8.0), $0.5 \mathrm{mM}$ rNTP, 8 mM $\mathrm{MgCl}_{2}, 5$ mM DTT, 2 mM sperimidine] and incubated at $37^{\circ}$ for $4 \mathrm{~h}$. Phenol:chloroform (1:1) was added, the mixture vortexed and ribozymes centrifuged at $16,000 \mathrm{~g}$ for $30 \mathrm{~s}$. The supernatant was transferred to a new tube, mixed with an equal amount of 25:1 chloroform:isoamyl alcohol, vortexed and centrifuged at $16,000 \mathrm{~g}$ for $30 \mathrm{~s}$. This supernatant was mixed with $200 \mu$ l of $100 \%$ ethanol and centrifuged at $16,000 \mathrm{~g}$ for $15 \mathrm{~min}$. The RNA pellet was washed twice with $75 \%$ ethanol, evaporated, and dissolved in $5 \mu \mathrm{l}$ of diethyl pyrocarbonate (DEPC)-treated water.

Before electrophoresis, $5 \mu \mathrm{l}$ of RNA was denatured at $90^{\circ}$ for $2 \mathrm{~min}$, then applied to $6 \%$ polyacrylamide sequence gel. After $1 \mathrm{~h}$ of electrophoresis at $300 \mathrm{~V}$, the gel was exposed onto film for 10 min. The RNA band was then excised from the gel at the position indicated by the radioactivity exposed film to recycle the RNA. Gel containing the RNA band was cut to small pieces in $400 \mu \mathrm{l}$ of DEPC-treated water, and shaken at $50^{\circ}$ for $2 \mathrm{~h}$ to extract the RNA, The supernatant was centrifuged at $14,000 \mathrm{rpm}, 4^{\circ}$ for $15 \mathrm{~min}$, the 


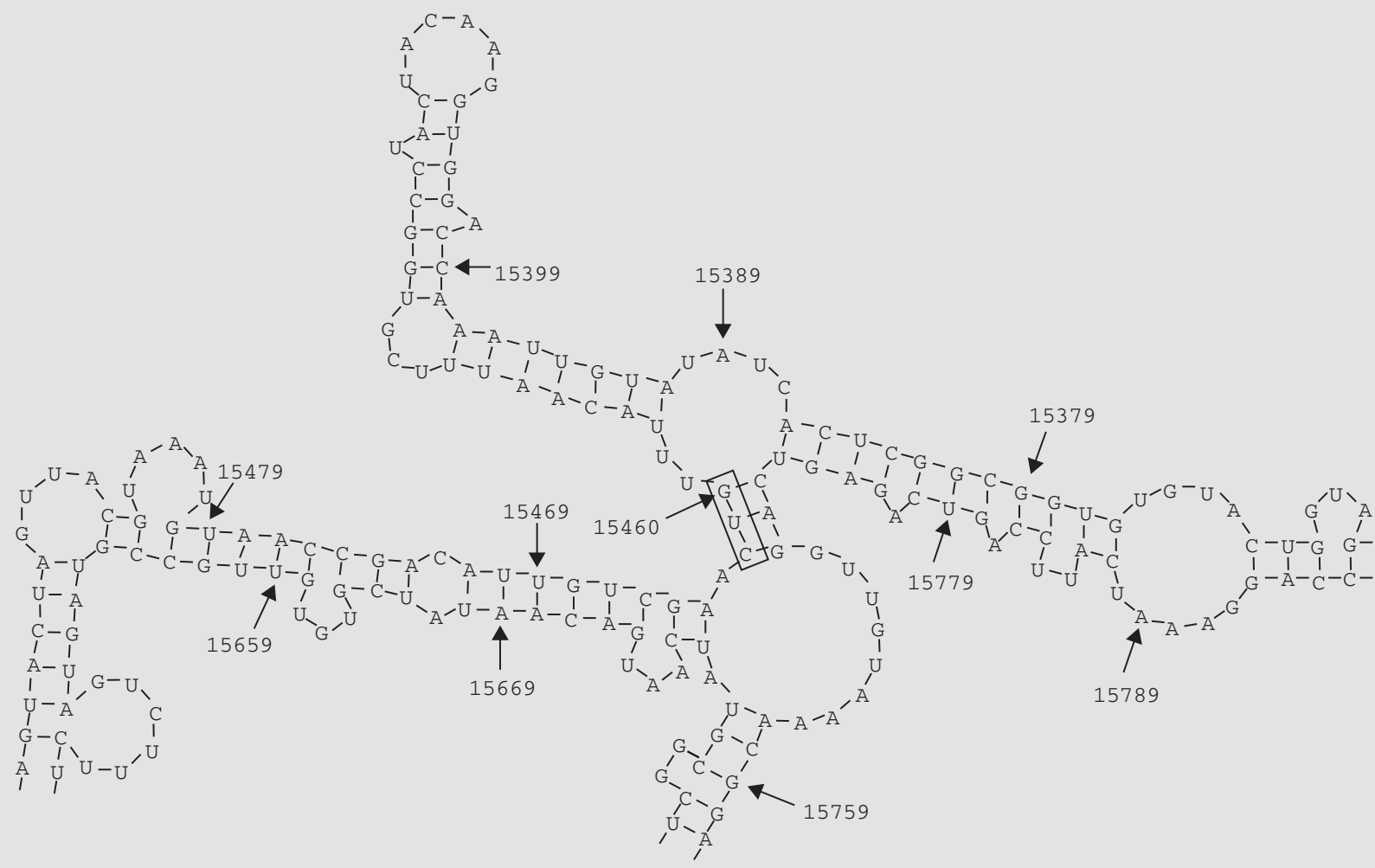

Fig. 1. Secondary structure of SARS-CoV RNA (from nucleotide 15365 to 15796) from GENETYX-MAC and the GUC cleavage sequence indicated by the box at the nucleotide 15460.

Fig. 2. a Sequence of target RNA around the cleavage site was common in SARSCoV RNA (NC_004718) and mouse hepatitis virus RNA. Sequence of ribozyme hybridization including GUC is underlined. b Sequence of the 38-base chimeric DNARNA hammerhead ribozyme. Ribonucleotides at noncatalytic residues were replaced with deoxyribonucleotides and two phosphorothioate linkages were added at the 3'-terminus for cleavage at the GUC sequence. Sequence of the 38-base mismatch ribozyme with three base changes in the catalytic core. Ribonucleotides of ribozymes are underlined. Phosphorothioate linkages are marked by asterisks.

\section{Target mouse hepatitis RNA}

15603

CUAGUAGUGGGGAUGCAACCACUGCUUUUGCUAAUUCUGUGUUUAACAUUUGUCAAGCUGUUUC CGCCAAUGUAUGCUCGCUUAUGGCAUGCAAUGGACA 15702

\section{Target SARS-CoV (NC_004718)}

$15409 \quad 15462$

CAUCAUCCGGUGAUGCUACAACUGCUUAUGCUAAUAGUGUCUUUAACAUUUGUCAAGCUGUUAC AGCCAAUGUAAAUGCACUUCUUUCAACUGAUGGUAA 15508

a

\section{Ribozyme}

3'-UGUAAACA UUCGACAA-5'

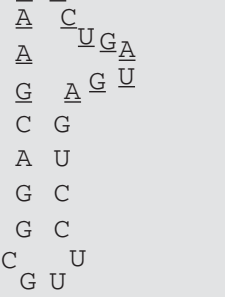

\section{Mismatch ribozyme}

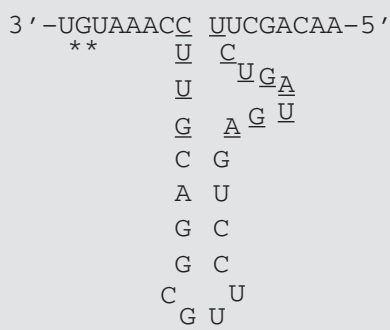


supernatant was transferred to a new tube, mixed with $40 \mu \mathrm{l}$ of $3 \mathrm{M}$ sodium acetate and 1,000 $\mathrm{ml}$ of $99 \%$ ethanol, and incubated at $-20^{\circ}$ for $1 \mathrm{~h}$. This was then centrifuged at $14,000 \mathrm{rpm}, 4^{\circ}$ for 15 min, the RNA pellet was washed twice with $75 \%$ ethanol and evaporated, then the RNA was dissolved in $50 \mu \mathrm{l}$ of DEPC-treated water, and stored at $-80^{\circ}$. RNA concentration was determined by UV spectrophotometry using a UV-1200 spectrophotometer (Shimadzu Co., Tokyo, Japan).

For in vivo experiments, chimeric DNA-RNA hammerhead ribozyme and mismatch ribozyme were synthesized with a DNARNA synthesizer (Applied Biosystems, Foster City, Calif., USA) and purified by high-performance liquid chromatography.

In vitro Cleavage Reactions with Ribozyme

In vitro cleavage reactions with the ribozyme were performed as described previously [17]. The ribozyme was annealed to the target RNA by combining $100 \mathrm{nM}$ ribozyme and $10 \mathrm{nM}$ target RNA in $20 \mu \mathrm{l}$ of $50 \mathrm{mM}$ Tris- $\mathrm{HCl}(\mathrm{pH} 8.0)$, heating at $90^{\circ}$ for $1 \mathrm{~min}$, then cooling to $37^{\circ}$ over $30 \mathrm{~min}$. The cleavage reaction was initiated by adding $2 \mu \mathrm{l}$ of $250 \mathrm{mM} \mathrm{MgCl}$ to the annealed ribozyme and target RNA in cleavage reaction buffer $[50 \mathrm{mM}$ Tris- $\mathrm{HCl}(\mathrm{pH}$ 8.0 ) and $25 \mathrm{mM} \mathrm{MgCl}_{2}$ ], then incubating at $37^{\circ}$ for 1 to $8 \mathrm{~h}$. The reaction was stopped by addition of bromophenol blue solution $(10 \mu \mathrm{l})$. Samples were heated at $90^{\circ}$ for $2 \mathrm{~min}$, then cooled quickly on ice. $5 \mu \mathrm{l}$ of each sample was loaded onto a sequencing gel for electrophoresis. The gel was dried and exposed to film.

\section{Evaluation of Effect of Chimeric Ribozyme on Multiplication} of $M H V$

DBT cells were seeded and grown in Dulbecco's modified Eagle's medium (DMEM) with 5\% calf serum (Gibco Life Technologies, Gaithersburg, Md., USA), with $250 \mu \mathrm{g} / \mathrm{ml}$ amphotericin B, and $50 \mathrm{mg} / \mathrm{ml} \mathrm{kanamycin.} \mathrm{Serum-free} \mathrm{DBT} \mathrm{cells} \mathrm{were} \mathrm{transfected}$ with $2.5 \mu \mathrm{M}$ ribozyme or mismatch ribozyme by $20 \mathrm{kDa}$ polyethylenimine reagent [18] and incubated for $2 \mathrm{~h}$ at $37^{\circ}$. DBT cells were infected with MHV at a multiplicity of infection of 0.01 for $45 \mathrm{~min}$ at $37^{\circ}$. Cells were then washed twice with PBS and incubated with DMEM with $5 \%$ calf serum for $12 \mathrm{~h}$. The conditioned medium was collected and MHV titer in the medium was determined by plaque assay using DBT cells. The viral titer was expressed as plaque-forming units (PFU)/ml.

RNA Extraction and Reverse Transcription-Polymerase Chain Reaction (RT-PCR) Assay for SARS-CoV

The recombinant pCR3 plasmid containing DNA encoding the target SARS-CoV RNA under control of the CMV promoter was transfected into NIH-3T3 cells (Sanko Jyunyaku Co., Tokyo, Japan) by lipofectin reagent (Gibco Life Technologies) according to the manufacturer's instructions. Cells were transfected with different concentrations of ribozyme or mismatch ribozyme, washed with PBS, lysed in $800 \mu \mathrm{l}$ of RNAzol, mixed with $80 \mu \mathrm{l}$ of chloroform, kept on ice for $15 \mathrm{~min}$, then centrifuged at $12,000 \mathrm{~g}$ for $15 \mathrm{~min}$ to extract total RNA. Aliquots of RNA $(1 \mu \mathrm{g} / 20 \mu \mathrm{l})$ were reverse-transcribed into single-stranded cDNA with 0.25 $\mathrm{U} / \mu \mathrm{l}$ avian myeloblastoma virus reverse transcriptase (Takara Biochemicals) in $10 \mathrm{~mm}$ Tris- $\mathrm{HCl}$ (pH 8.3), $5 \mathrm{mM} \mathrm{MgCl}_{2}, 50 \mathrm{mM}$ $\mathrm{KCl}, 1 \mathrm{mM}$ deoxy-NTPs, and $2.5 \mu \mathrm{M}$ random hexamers. Diluted cDNA product $(2 \mu \mathrm{l})$ was mixed with $10 \mathrm{~mm}$ Tris- $\mathrm{HCl}(\mathrm{pH} 8.3)$, $50 \mathrm{mM} \mathrm{KCl}, 4 \mathrm{mM} \mathrm{MgCl}_{2}$, and $0.025 \mathrm{U} / \mu \mathrm{l} \mathrm{Taq}$ DNA polymerase (Takara Biochemicals), and $0.2 \mu \mathrm{M}$ each of the forward primer

Development of a Ribozyme Targeting SARS Virus
(5'-TCTGAGTAGGTACCTGGCACTAGTAGTGGGG-3') and the reverse primer (5'-CAGTCGTATCTAGAAAGCGAGCATACATTGGC-3') in a total volume of $25 \mu \mathrm{l}$. PCR conditions consisted of initial denaturation at $94^{\circ}$ for $3 \mathrm{~min}$, followed by 25 cycles of: denaturation for $30 \mathrm{~s}$ at $94^{\circ}$, annealing for $30 \mathrm{~s}$ at $55^{\circ}$, and extension for $1 \mathrm{~min}$ at $72^{\circ}$; with a final extension for $10 \mathrm{~min}$ at $72^{\circ}$. Primers for $18 \mathrm{~S}$ rRNA were included in each reaction as an internal control. PCR products were separated by electrophoresis on $1.5 \%$ agarose gels. Band intensity was measured by computer analysis using NIH software.

\section{Statistical Analysis}

Results are reported as the mean \pm SEM. Differences between mean values were evaluated by Student's t test. A p value $<0.05$ was considered to be significant.

\section{Results}

\section{In vitro Cleavage Reaction with Ribozyme}

Figure 3 shows in vitro cleavage reaction of synthetic target RNA with the chimeric DNA-RNA hammerhead ribozyme targeting SARS-CoV. In the presence of $\mathrm{MgCl}_{2}$, the synthetic ribozyme cleaved target RNA encoding both of MHV RNA and SARS-CoV RNA, respectively, into fragments that were consistent with predicted sizes. Mismatch ribozyme did not cleave the target RNA. This indicated the synthetic ribozyme specifically cleaved the target MHV RNA and SARS-CoV RNA.

\section{Effect of the Chimeric Ribozyme on Multiplication of $M H V$}

Figure 4 shows effect of the chimeric DNA-RNA hammerhead ribozyme targeting SARS-CoV RNA on the multiplication of MHV in DBT cells. The ribozyme was transfected to DBT cells and the transfection efficiency of FITC-labeled ribozyme in DBT cells by $20 \mathrm{kDa}$ polyethylenimine was around $60 \%$. The transfected cells were infected with MHV. The chimeric ribozyme targeting SARS-CoV RNA significantly reduced viral titer in the medium of the infected cells compared to cells treated with mismatch ribozyme.

\section{Effect of the Ribozyme on SARS-CoV RNA Expression}

Figure 5 shows effect of the chimeric ribozyme targeting SARS-CoV RNA on expression of the SARS-CoV RNA transcribed from the recombinant $\mathrm{pCR} 3$ plasmid in 3T3 cells. Concentrations of 1.0, 10 and $100 \mathrm{nM}$ of the chimeric ribozyme significantly reduced abundance of the SARS-CoV RNA in a dose-dependent manner. Mismatch ribozyme did not affect expression of the SARSCoV RNA. 


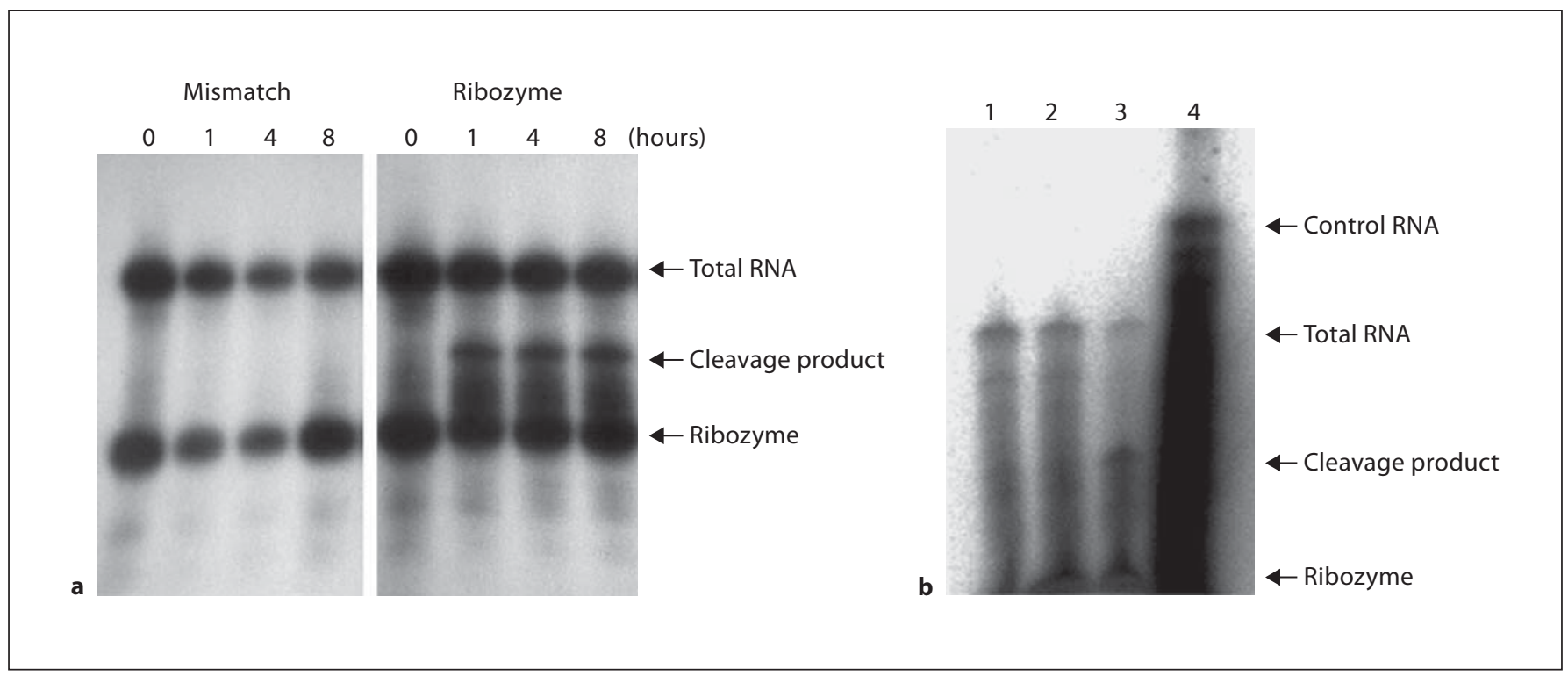

Fig. 3. In vitro cleavage reactions of target MHV RNA and SARSCoV RNA with chimeric DNA-RNA hammerhead ribozyme targeting SARS-CoV RNA. a For cleavage reactions synthetic 90base target MHV RNA and the 38-base ribozyme were incubated for 1,4 , and $8 \mathrm{~h}$. The ribozyme cleaved the target MVH RNA to the predicted 62-base fragment. Mismatch ribozyme did not cleave the target MHV RNA. b Synthetic 196-base target SARSCoV RNA and the 38-base ribozyme were incubated for $2 \mathrm{~h}$. The ribozyme cleaved the target SARS-CoV RNA to the predicted 120-base fragment. Mismatch ribozyme did not cleave the target SARS-CoV RNA. Lanes: (1) without ribozyme, (2) mismatch ribozyme, (3) SARS ribozyme, and (4) control RNA.

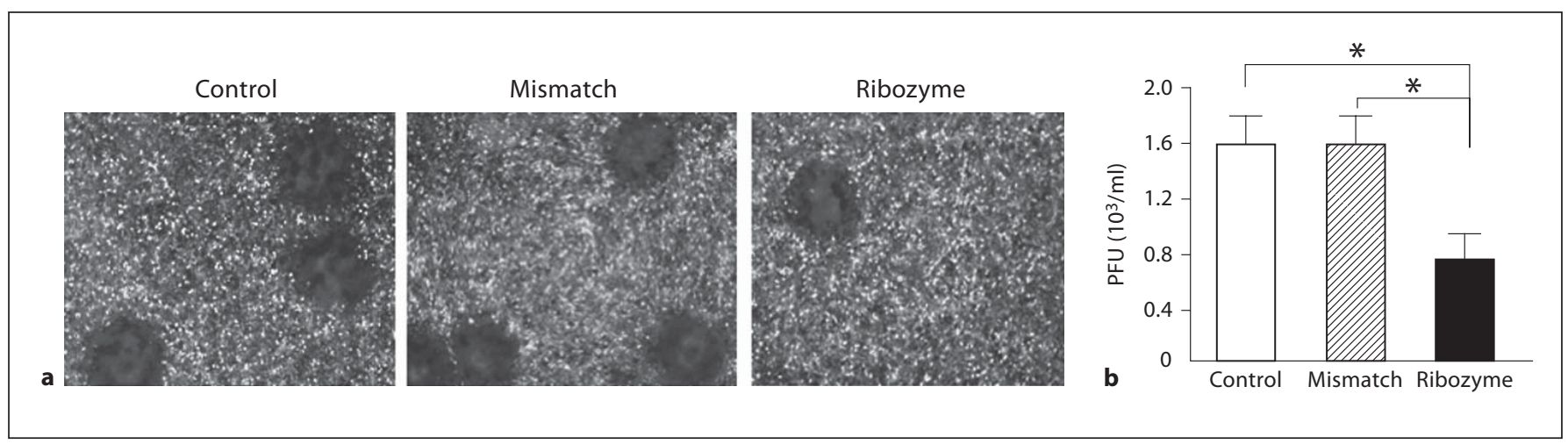

Fig. 4. Effects of chimeric DNA-RNA hammerhead ribozyme targeting SARS-CoV RNA on multiplication of MHV in DBT cells. Serum-free DBT cells were transfected with $2.5 \mu \mathrm{M}$ ribozyme or mismatch ribozyme by $20 \mathrm{kDa}$ polyethylenimine reagent and incubated for $2 \mathrm{~h}$ (multiplicity of infection). DBT cells were infected with MHV at a multiplicity of infection of 0.01 for $45 \mathrm{~min}$. The conditioned medium was collected and added in new DBT cells. Plaque assays were performed to titrate infectious progeny.
The viral titer was expressed as plaque-forming units (PFU)/ml. a Representative plaque formation of MHV in DBT cells treated without (Control) and with mismatch ribozyme (Mismatch) or chimeric DNA-RNA hammerhead ribozyme targeting SARSCoV RNA (Ribozyme). b Comparison of PFU of MHV in DBT cells. Data are mean $\pm \operatorname{SEM}(n=6) .{ }^{*} \mathrm{p}<0.05$ between indicated columns. 


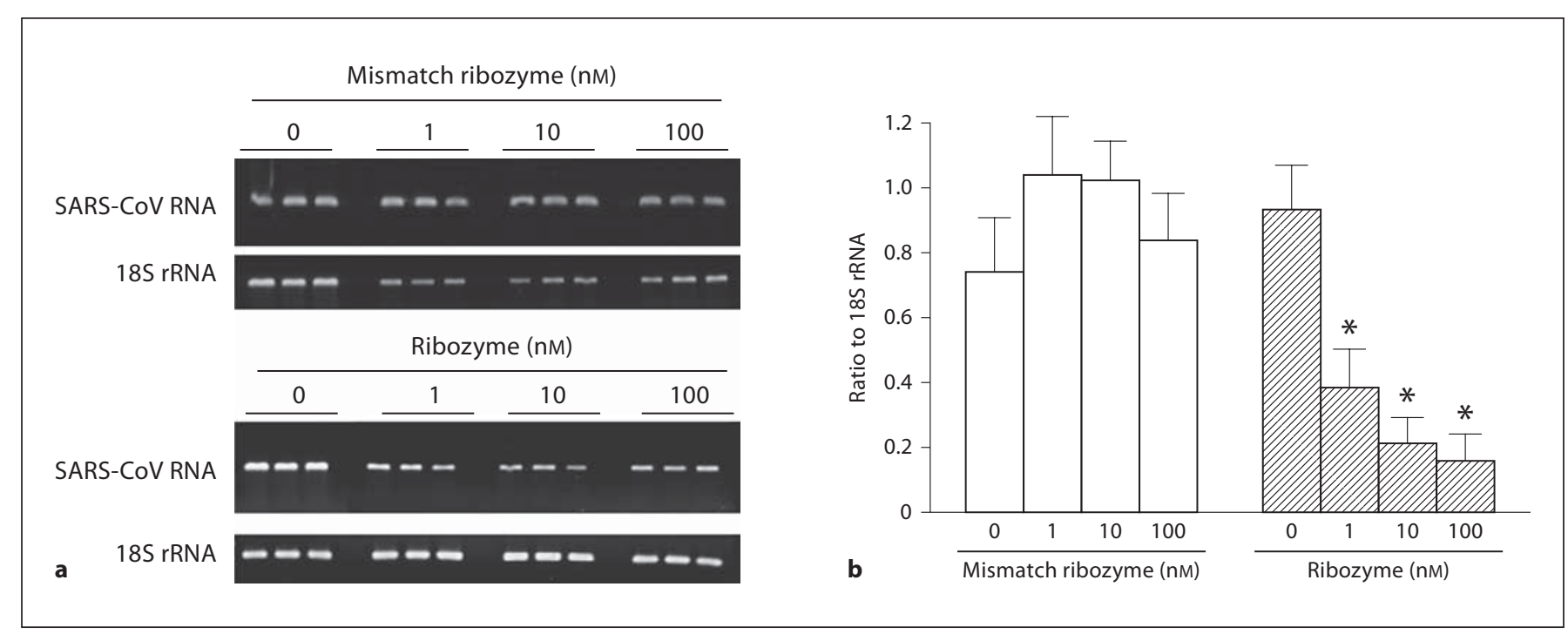

Fig. 5. Effect of the synthetic chimeric DNA-RNA hammerhead ribozyme on expression of SARS-CoV RNA in 3T3 cells. Recombinant plasmids encoding the SARS-CoV RNA fragment were transfected into 3T3 cells by lipofectin reagent. Cells were treated with concentrations of 1.0, 10 and $100 \mathrm{nM}$ ribozyme or mismatch ribozyme. The ratio of the abundance of each mRNA to that of $18 \mathrm{~S}$ rRNA was evaluated by densitometric analysis. Data are mean $\pm \operatorname{SEM}(n=6) .{ }^{*} \mathrm{p}<0.01$ vs. without ribozyme.

\section{Discussion}

To date, several clinical trials of ribozymes have been reported. A retrovirally expressed ribozyme targeting HIV tat is currently in phase II testing for patients with HIV-related lymphoma. The antiangiogenic ribozyme targeting VEGF-R1 is currently in phase II trials for several tumor types. A ribozyme targeting the 5'-untranslated region of the hepatitis $C$ virus RNA genome has recently passed through a phase I/II clinical trial in patients with chronic hepatitis C [19]. On the other hand, short interfering RNA (siRNA) (composed of doublestranded RNA which also triggers the silencing of gene expression in a sequence-specific manner) has shown potential as a strong nucleic acid medicine for severe disease. siRNA has been successfully shown to inhibit different stages of HIV-1 replication [20]. However, the interferon-induced effects of siRNA could exert nonspecific inhibition of gene expression. This remains an issue for the development of siRNA as a next generated gene therapy agent $[21,22]$.

The viruses most susceptible to ribozymes may be those in which all aspects of the viral life cycle are RNA dependent, with no DNA intermediate. There are several classes of ribozyme, one of which is the hammerhead, found in vivo in plant viroids and virusoids and in tran- scripts of new satellite DNA [23, 24]. In their natural environment, these enzymes cleave intramolecularly, cutting $3^{\prime}$ to a required sequence, usually GUC. Hammerhead ribozymes contain two functional modules: a catalytic core which cleaves the target RNA and contains several conserved bases, and flanking regions which, through nucleic acid complementarity, direct the ribozyme core to a specific target site. By exploiting the flexibility of these two modular functions, ribozymes could potentially be designed to specifically cleave almost any target RNA molecule [25]. Cleaved mRNA is rapidly degraded, allowing the ribozyme to dissociate and react with new target RNA.

The cleavage site and both binding arms need to be considered when ribozymes are designed to target a specific RNA. First of all, the cleavage site should be located within an important functional region of the target gene to ensure the corresponding protein's function is lost after cleavage. In addition, the flanking sequences around the cleavage site should be as conserved as possible so that the ribozyme cleavage spectrum will remain broad [26]. SARS-CoV structure is composed of RNAs encoding repricase, spike, envelope, membrane glycoprotein, and nucleocapside protein $[27,28]$. Since the spike structure RNA sequence is subject to rapid mutagenesis, the target cleavage site of a ribozyme should be located in the other 
viral RNA sequences. If the target GUC cleavage sequence of a ribozyme is located within a stem structure of target mRNA, the mRNA function is not suppressed. This is because the secondary structure makes the site less accessible. To ensure a stem structure was not present at the target GUC cleavage site, we analyzed the secondary structure of SARS-CoV RNA [27], and selected an optimal cleavage site where both binding arms target a loop structure that exposes the RNA sequence for the ribozyme cleavage interaction.

An experiment with actual SARS- $\mathrm{CoV}$ could not be performed in the present study because of its infection risk. Therefore, the chimeric DNA-RNA hammerhead ribozyme was designed with complementarity to common regions of SARS-CoV and MHV that included the target GUC sequence. The ability of the ribozyme to cleave synthetic target RNA encoding a SARS-CoV RNA was then assessed in vitro, and effectiveness of the ribozyme to inhibit MVH virus multiplication evaluated in DBT cells. $\mathrm{MHV}$ is a single-stranded RNA virus of the family Coronaviridae and belongs to the group II coronaviruses. Clinical infection occurs when the virus is introduced into a naive colony of mice. Coronaviruses typically have narrow host ranges and are fastidious in cell culture. Mice are the only host for MHV, although other rodent species may carry serum antibodies to the virus. In cell culture, MHV forms plaques upon multiplication in DBT cells. In the present study, inhibition on the multiplication of $\mathrm{MVH}$ was approximately $60 \%$, with $60 \%$ transfection efficiency of the chimeric DNA-RNA ribozyme targeting SARS$\mathrm{CoV}$ into DBT cells. This indicated that the ribozyme inhibited viral activity. In addition, it was demonstrated that the chimeric ribozyme significantly inhibited ex-

be applied in tissues, a high catalytic efficiency, stability, and adequate levels of the ribozyme are necessary. A number of modifications can improve stability, specificity, and efficacy of ribozymes. Ribozymes can also be successfully delivered exogenously by transfection of cells with cationic liposomes [29]. A recent study showed that the chimeric DNA-RNA hammerhead ribozyme had enhanced catalytic turnover and stability [30]. In addition, a chimeric ribozyme containing phosphorothioate linkage further improved its resistance to nucleases [31, 32]. In the present study, we designed and synthesized a chimeric DNA-RNA hammerhead ribozyme which was modified with phosphorothioate linkages at the 3 '-terminus.

Delivery reagents such as liposome or polyethylenimine should be used to prevent degradation of the ribozyme. Since polyethylenimine has been reported to protect the ribozyme from degradation by nucleases (in addition to assisting ribozyme delivery into tissue in vivo) [33], polyethylenimine was used as a delivery reagent for the ribozyme in this study. Since SARS induces pneumonia, delivery of the ribozyme intravenously or through the air way would be beneficial. Further studies are required to determine the optimal methods for therapeutic application of ribozymes against SARS-CoV.

From this study, the synthesized chimeric DNA-RNA ribozyme targeting SARS-CoV significantly inhibited MHV viral activity and expression of SARS-CoV RNA. The chimeric ribozyme will be a feasible treatment for SARS. pression of synthetic SARS-CoV RNA transcribed from pCR3 plasmid in 3T3 cells. These findings suggest that this ribozyme could be useful for the treatment of SARS.

To confirm the effects of the ribozyme on viral multiplication in vivo, experiments need to be performed in mice. For in vivo application of the chimeric ribozyme, the optimal method of delivery should be assessed. The advantage of the application of a ribozyme targeting SARS, compared to vaccines, is the expected rapid application possible and higher effectiveness of ribozyme treatment. However, one significant problem for the use of ribozymes as gene therapeutics is the degradation of ribozyme in vivo. RNA ribozymes are rapidly degraded in both culture medium and living cells by RNase, which diminishes copy number of the ribozyme. Thus, ribozyme therapy is not suitable for chronic diseases, but is suitable for acute diseases such as SARS. For ribozymes to

References
1 Groneberg DA, Zhang L, Welte T, Zabel P, Chung KF: Severe acute respiratory syndrome: global initiatives for disease diagnosis. QJM 2003;96:845-852.

2 Peiris JS, Lai ST, Poon LL, Guan Y, Yam LY, Lim W, Nicholls J, Yee WK, Yan WW, Cheung MT, Cheng VC, Chan KH, Tsang DN, Yung RW, Ng TK, Yuen KY: SARS study group. Coronavirus as a possible cause of severe acute respiratory syndrome. Lancet 2003;361:1319-1325.

- 3 Drosten C, Gunther S, Preiser W, van der Werf S, Brodt HR, Becker S, Rabenau H, Panning M, Kolesnikova L, Fouchier RA, Berger A, Burguiere AM, Cinatl J, Eickmann M, Escriou N, Grywna K, Kramme S, Manuguerra JC, Muller S, Rickerts V, Sturmer M, Vieth S, Klenk HD, Osterhaus AD, Schmitz H, Doerr HW: Identification of a novel coronavirus in patients with severe acute respiratory syndrome. N Engl J Med 2003;348:1967-1976.

-4 Peiris JS, Yuen KY, Osterhaus AD, Stohr K: The severe acute respiratory syndrome. $\mathrm{N}$ Engl J Med 2003;349:2431-2441.

Fukushima et al. 
$\checkmark 5$ Leung GM, Hedley AJ, Ho LM, Chau P, Wong IO, Thach TQ, Ghani AC, Donnelly CA, Fraser C, Riley S, Ferguson NM, Anderson RM, Tsang T, Leung PY, Wong V, Chan JC, Tsui E, Lo SV, Lam TH: The epidemiology of severe acute respiratory syndrome in the 2003 Hong Kong epidemic: an analysis of all 1,755 patients. Ann Intern Med 2004;141: 662-673.

6 Wu YS, Lin WH, Hsu JT, Hsieh HP: Antiviral drug discovery against SARS-CoV. Curr Med Chem 2006;13:2003-2020.

7 Haagmans BL, Osterhaus AD: Coronaviruses and their therapy. Antiviral Res 2006;71: 397-403.

$\checkmark 8$ Baric RS, Sheahan T, Deming D, Donaldson E, Yount B, Sims AC, Roberts RS, Frieman M, Rockx B: SARS coronavirus vaccine development. Adv Exp Med Biol 2006;581:553560.

9 Ohkawa J, Koguma T, Kohda T, Taira K: Ribozymes: from mechanistic studies to applications in vivo. J Biochem 1995;118:251258.

10 Vaish NK, Kore AR, Eckstein F: Recent developments in the hammerhead ribozyme field. Nucleic Acids Res 1998;26:5237-5242.

- 11 Teng J, Fukuda N, Hu WY, Nakayama M, Kishioka H, Kanmatsuse K: DNA-RNA chimeric hammerhead ribozyme to transforming growth factor- $\beta_{1}$ mRNA inhibits the exaggerated growth of vascular smooth muscle cells from spontaneously hypertensive rats. Cardiovasc Res 2000;48:138-147.

-12 Hu WY, Fukuda N, Kishioka H, Nakayama $\mathrm{M}$, Kanmatsuse K: Inhibition of vascular smooth muscle cell proliferation by DNARNA chimeric hammerhead ribozyme targeting to rat PDGF A-chain mRNA. J Hypertens 2001;19:203-212.

>13 Hong SH, Jeong JS, Lee YJ, Jung HI, Cho KS, Kim CM, Kwon BS, Sullenger BA, Lee SW, Kim IH: In vivo reprogramming of hTERT by trans-splicing ribozyme to target tumor cells. Mol Ther 2007;16:74-80.

14 Scherer L, Rossi JJ, Weinberg MS: Progress and prospects: RNA-based therapies for treatment of HIV infection. Gene Ther 2007; 14:1057-1064.
15 Milligan JF, Groebe DR, Witherell GW, Uhlenbeck OC: Oligoribonucleo-tide synthesis using T7 RNA polymerase and synthetic DNA templates. Nucleic Acids Res 1987; 15:8783-8798.

16 Uhlenbeck OC: A small catalytic oligoribonucleotide. Nature 1987;328:596-600.

-17 Saxena SK, Ackerman EJ: Ribozymes correctly cleave a model substrate and endogenous RNA in vivo. J Biol Chem 1990;265: 17106-17109.

-18 Boussif O, Lezoualch F, Zanta MA, Mergny MD, Scherman D, Demeneix B, Behr JP: A versatile vector for gene and oligonucleotide transfer into cells in culture and in vivo: polyethylenimine. Proc Natl Acad Sci USA 1995;92:7297-7301.

19 Macejak D, Jensen KL, Jamison S, Domenico K, Roberts EC, Chaudhary N, von Carlowitz I, Bellon L, Tong MJ, Conrad A, Pavco PA, Blatt LM: Inhibition of hepatitis $\mathrm{C}$ virus (HCV)-RNA-dependent translation and replication of a chimeric $\mathrm{HCV}$ poliovirus using synthetic stabilized ribozymes. Hepatology 2000;31:769-776.

20 Hayafune M, Miyano-Kurosaki N, Park WS, Moori Y, Takaku H: Silencing of HIV-1 gene expression by two types of siRNA expression systems. Antivir Chem Chemother 2006;17: 241-249.

-21 Kariko K, Bhuyan P, Capodici J, Weissman D: Small interfering RNAs mediate sequence-independent gene suppression and induce immune activation by signaling through toll-like receptor 3. J Immunol 2004; 172:6545-6549.

22 Epstein L, Gall JG: Self-cleaving transcripts of satellite DNA from the newt. Cell 1987;48: 535-543.

-23 Buzayan JM, Gerlach WL, Bruening G: Nonenzymatic cleavage and ligation of RNAs complementary to a plant virus satellite RNA. Nature 1986;323:349-353.

24 Forster AC, Symons RH: Self-cleavage of plus and minus RNA of a virusoid and a structural model for the active sites. Cell 1987;49:211-220.

25 Xing Z, Whitton JL: Ribozymes which cleave arenavirus RNAs: identification of susceptible target sites, and inhibition by target site secondary structure. J Virol 1992;66:13611369.
26 Heidenreich O, Eckstein F: Hammerhead ribozyme-mediated cleavage of the long terminal repeat RNA of human immunodeficiency virus type 1. J Biol Chem 1992;267: 1904-1909.

-27 Campanacci V, Egloff MP, Longhi S, Ferron F, Rancurel C, Salomoni A, Durousseau C, Tocque F, Bremond N, Dobbe JC, Snijder EJ, Canard B, Cambillau C: Structural genomics of the SARS coronavirus: cloning, expression, crystallization and preliminary crystallographic study of the Nsp9 protein. Acta Crystallogr D Biol Crystallogr 2003;59: 1628-1631.

28 Dawson PA, Marini JC: Hammerhead ribozymes selectively suppress mutant type 1 collagen mRNA in osteogenesis imperfecta fibroblasts. Nucleic Acids Res 2000;28:40134020 .

-29 Duzgunes N, Pretzer E, Simoes S, Slepushkin V, Konopka K, Flasher, D, de Lima MC: Liposome-mediated delivery of antiviral agents to human immunodeficiency virusinfected cells. Mol Membr Biol 1999;16:111118.

30 Kotani M, Fukuda N, Ando H, Hu WY, Kunimoto S, Kanmatsuse K, Saito S: Chimeric DNA-RNA hammerhead ribozyme targeting to PDGF A-chain mRNA specifically inhibited neointima formation of rat carotid artery after balloon injury. Cardiovasc Res 2003;57:265-276.

-31 Taylor NR, Kaplan BE, Swidersk P, Li H, Rossi JJ: Chimeric DNA-RNA hammerhead ribozymes have enhanced in vitro catalytic efficiency and increased stability in vivo. Nucleic Acid Res 1992;20:4559-4564.

\32 Shimayama T, Nishikawa F, Nishikawa S, Taira K: Nuclease-resistant chimeric ribozymes containing deoxyribonucleotides and phosphorothioate linkages. Nucleic Acid Res 1993;21:2605-2611.

33 Boussif O, Lezoualch F, Zanta MA, Mergny MD, Scherman D, Demeneix B, Behr JP: A versatile vector for gene and oligonucleotide transfer into cells in culture and in vivo: polyethylenimine. Proc Natl Acad Sci USA 1995;92:7297-7301. 